\title{
Sea urchin Diadema antillarum: different functions in the structure and dynamics of reefs on both sides of the Atlantic
}

\author{
Fernando Tuya ${ }^{1, *}$, Ricardo J. Haroun ${ }^{1}$, Arturo Boyra ${ }^{1}$, Pablo Sanchez-Jerez ${ }^{2}$ \\ ${ }^{1}$ BIOGES, Department of Biology, Campus Tafira, University of Las Palmas de G.C., 35017 Las Palmas, Canary Islands, Spain \\ ${ }^{2}$ Marine Biology Lab, Department of Marine Sciences, University of Alicante, POB 99, 03080 Alicante, Spain
}

\begin{abstract}
The long-spined black sea urchin Diadema antillarum has been involved in phase shifts between 'desired' and 'undesired' states in the organization of shallow reefs on both sides of the Atlantic Ocean between 18 and $33^{\circ} \mathrm{N}$, but with significantly different ecological outcomes. In the western Atlantic, high densities of $D$. antillarum previously exerted considerable grazing pressure on reefs where corals and turf algae were the main biological engineers; however, subsequent to a massive die-off of $D$. antillarum from disease in 1983-1984, many reefs have gradually become dominated by foliose algae. In contrast, hyperabundances of $D$. antillarum $\left(>10\right.$ ind. $\left.\mathrm{m}^{-2}\right)$ in the eastern Atlantic have caused the elimination of erect vegetative frameworks with the subsequent creation of 'barrens'. As a result, this invertebrate is directly implicated in the 'health' of important components of the biogenic frameworks of reefs on both sides of the Atlantic Ocean. Efforts in the western Atlantic are concentrated on the restoration of populations of $D$. antillarum to enhance coral abundance, recruitment and survivorship, while ecologists and managers in the eastern Atlantic focus on possible mechanisms to control hyperabundances of this species. We believe that the disproportionate effects of a single herbivorous species in mediating transitions between alternate states on the 2 sides of the Atlantic Ocean may be a direct consequence of a decline in the resilience of coastal ecosystems to disturbance. This decline was principally caused by decreased diversity of many of the functional groups that inhabit the Atlantic Ocean; both the western and eastern Atlantic Ocean have experienced large reductions in predatory and other fish populations.
\end{abstract}

KEY WORDS: Sea urchins - Reefs - Alternate states - Regime shifts · Community organization · Atlantic Ocean $\cdot$ Bioengineers $\cdot$ Diadema antillarum

\section{INTRODUCTION}

Anthropogenic disturbance and climate change have caused dramatic shifts in the organization and structure of many coastal communities, with the establishment of alternate stable states (Knowlton 2004). These changes are generally long lasting and difficult to reverse (Scheffer et al. 2001, Scheffer \& Carpenter 2003, Folke et al. 2004, Hughes et al. 2005), resulting in severe economic loss (Bellwood et al. 2004). The extent to which alternate states are stable or reversible is poorly understood, and this represents a major challenge for research and management of coastal reefs worldwide (Bellwood et al. 2004, Knowlton 2004). Moreover, regime shifts have important implications for the formulation of management strategies, as 'undesired' states (from a human perspective) with high resistance to restoration may develop.

Subtidal ecosystems are different on both sides of the Atlantic in the latitude belt between 18 and $33^{\circ} \mathrm{N}$. 
This difference arises mostly because the warm-temperate region is situated almost $5^{\circ}$ further south at the Atlantic coast of North America (Briggs 1974, Lüning 1990) compared to the eastern Atlantic; thus, coral reefs are asymmetrically distributed on either side of the Atlantic. Marine environments within this latitudinal belt in the western Atlantic comprise warmtemperate and tropical waters (Briggs 1974, Lüning 1990), including the northern USA coast of the Gulf of Mexico (SST range: 13 to $30^{\circ} \mathrm{C}$ ) and a part of the Caribbean Sea (SST range: 24 to $30^{\circ} \mathrm{C}$ ). In contrast, the eastern Atlantic comprises only warm-temperate waters (SST range: 16 to $24^{\circ} \mathrm{C}$ ) (Briggs 1974, Lüning 1990). These different oceanographic regimes impose limitations on the development of marine ecosystem engineers (species that create more complex habitat), which result in the presence and dominance of different subtidal habitats on both sides of the Atlantic Ocean. For example, corals and turf algae in the warm tropical waters of the western Atlantic (e.g. the Caribbean Sea) structure the physical and biological components of their environment. In contrast, erect macroalgae provide the main biological substrate for many organisms in the eastern Atlantic (e.g. the Canarian and Madeira Archipelagos) where coral reefs do not exist.

Despite the existence of remarkable oceanographic and biogeographic barriers, certain widespread marine species are endemic to both sides of the Atlantic.

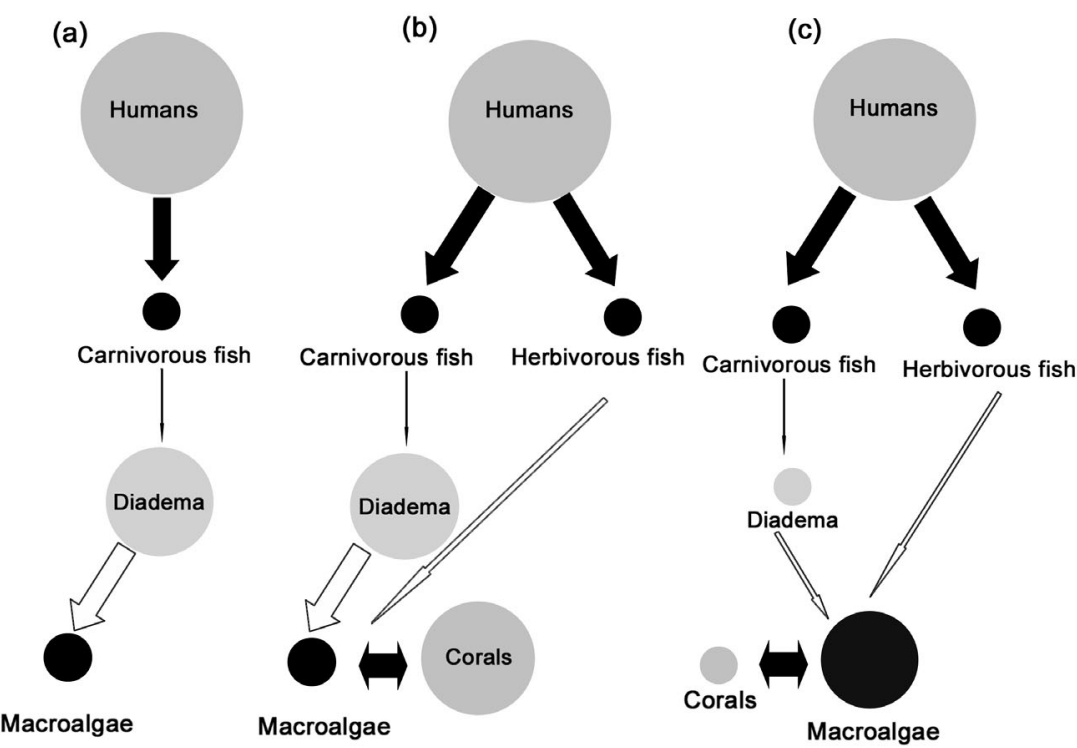

Fig. 1. Schematic representation of functional food webs on both sides of the Atlantic Ocean in the latitude-belt between 18 and $33^{\circ} \mathrm{N}$ : (a) eastern Atlantic, (b) western Atlantic prior to the 1983-1984 massive disease-induced die-off of Diadema antillarum, and (c) western Atlantic after the disease outbreak. Size of circles is proportional to the approximate biomass of each group; single-headed black arrows indicate predation; single-headed outline arrows indicate herbivory; width of the arrows reflects strong (wide) or weak (narrow) interactions; double-headed black arrows represent strong interspecific competition
One of these species, the long-spined black sea urchin Diadema antillarum (Philippi) has been at the core of extensive research along both Atlantic coasts since the 1970s, although its ecological importance along the eastern Atlantic has only been highlighted in recent years (Alves et al. 2001, 2003, Tuya et al. 2004a,b). Genetic studies have revealed that populations of this echinoid from the western and eastern Atlantic have been isolated, in terms of their evolution, for more than 1.5 million years (Lessios et al. 2001). The aim of this study is to compare the different ecological functions hat $D$. antillarum plays in the structure and dynamics 18 and $33^{\circ} \mathrm{N}$.

\section{ECOLOGICAL FUNCTION OF DIADEMA ANTILLARUM}

\section{Biotopes in the western Atlantic}

Decreases in fish populations in the last century have altered the structure of functional groups of herbivores on many reefs, especially during the last 3 decades (Edmunds \& Carpenter 2001, Gardener et al. 2003, Pandolfi et al. 2003, Bellwood et al. 2004). In response, herbivory has shifted from being fish-dominated to becoming echinoid-dominated (Bellwood et al. 2004) (Fig. 1). In this respect, a major ecological consequence of the massive die-off from disease of Diadema antillarum in the western Atlantic during 1983-1984 has been the abundant growth of erect algae (Lessios 1988a, Lessios 1988b, Hughes 1994, Bellwood et al. 2004). Without the grazing pressure exerted by high densities of $D$. antillarum, many reefs where corals and turf algae were the main biological reef engineers have gradually become dominated by erect foliose macroalgae (Hughes 1994, Edmunds \& Carpenter 2001, Bellwood et al. 2004). Macroalgae outcompete corals by directly overgrowing them, or by occupying available space and thus inhibiting outward growth of existing colonies and recruitment of new colonies (Williams \& Polunin 2001 and references therein). Over the last few years, reduced macroalgal cover and increased abundance of juvenile corals has resulted from natural recovery of $D$. antillarum populations at some sites in the Caribbean (Edmunds \& Carpenter 2001, Miller et al. 2003), and through 
experimental manipulation of $D$. antillarum abundance in the Florida Keys (Nedimyer \& Moe 2003). This recovery provides evidence of the initiation of a reversal from a 'less desirable' macroalgal stable state to a coraldominated system, suggesting that macroalgae dominance of Caribbean reefs is not an irreversible consequence of natural and anthropogenic disturbances (Edmunds \& Carpenter 2001).

\section{Biotopes in the eastern Atlantic}

In the eastern Atlantic, the scenario differs markedly. Removal of top predators during the last few decades as a consequence of overfishing has been linked to hyperabundances $\left(>10\right.$ ind. $\mathrm{m}^{-2}$ ) of sea urchins (predominantly Diadema antillarum), with the subsequent elimination of erect vegetative frameworks and the creation of barrens as an alternate stable state (Fig. 1) (Tuya et al. 2004a). This process follows the classical trophic-cascade paradigm of subtidal temperate rocky reefs (Sala \& Zabala 1996, Estes et al. 1998, Pinnegar et al. 2000, Shears \& Babcock 2003, Graham 2004), in that urchin barrens may be considered as a global phenomenon mediated by overexploitation of inshore resources (Sala et al. 1998, Knowlton 2004). Consequently, $D$. antillarum plays an important ecological role in the organization of rocky reefs across the eastern Atlantic, as this species determines the composition and structure of benthic algal communities by inhibiting the development of the physical structure and primary resources provided by macroalgae (Alves et al. 2001，2003, Tuya et al. 2004a,b). In this case, the lack of a vegetative framework imposes important limitations on the available food and refuge for a great number of species, with the establishment of an 'undesired' stable state dominated by crustose algae and barren habitat. Empirical evidence of natural reversals from a 'barren state' to a macroalgal-dominated system is still sparse.

\section{‘Desired' versus ‘undesired' states}

Diadema antillarum is therefore currently involved in the dominance and persistence of 'desired versus undesired' states in the organization of reefs on both sides of the Atlantic Ocean, but with completely opposite scenarios. In other words, this sea urchin is directly implicated in the phase shifts (sensu Knowlton 2004) of the major components of the biogenic frameworks of reefs on both sides of the Atlantic (Fig. 1). Ironically, efforts in the western Atlantic are concentrated on the restoration of populations of $D$. antillarum to enhance coral abundance, recruitment and survivor- ship (Edmunds \& Carpenter 2001, Nedimyer \& Moe 2003), whereas ecologists and managers in the eastern Atlantic focus on possible mechanisms to control and decrease the hyperabundances of this species and thus allow erect macroalgae to recolonise unvegetated (barren) areas. Nonetheless, before 1983, efforts should have been focused in the same direction on both sides of the Atlantic (H. A. Lessios pers. comm.), principally because both the western and eastern Atlantic experienced large reductions in predatory and herbivorous fish populations. The mass mortality of D. antillarum in the western Atlantic was the cause of currently opposite situations on either side of the Atlantic.

It has been speculated that hyperabundances of Diadema antillarum in the 1970s across the Caribbean, principally associated with the elimination of competitors (herbivorous fish) and predators (carnivorous fish) through overexploitation, may have contributed to the species' own demise in 1983-1984 (Bellwood et al. 2004). At this time a pathogen spread throughout the Caribbean and reduced numbers of $D$. antillarum by 2 orders of magnitude (Lessios et al. 1984, Lessios $1988 \mathrm{~b})$ and precipitated the growth of macroalgae on coral reefs with the subsequent loss of coral cover (Bellwood et al. 2004, Hughes et al. 2005). However, no massive die-off event has been recorded in the eastern Atlantic over the last several decades, where mean local densities can easily reach up to 10 ind. $\mathrm{m}^{-2}$. If the species' own demise is linked to its hyperabundance, the why have mass mortalities not occurred in the eastern Atlantic? Apparently, such a die-off would directly benefit the recovery of the main bioengineers (erect macroalgae) of the shallow hard bottoms of the eastern Atlantic.

\section{CONCLUSIONS}

Distortion of food webs by humans, induced by selectively removing top predators and herbivores, has damaged the resilience of marine systems (Myers \& Worm 2003, Hughes et al. 2005), with the establishment of 'undesired' alternate organizational states (Knowlton 2004, Hughes et al. 2005). We believe that the disproportionate effects of a single herbivorous species Diadema antillarum in mediating transitions ('phase shifts') between alternate states on both sides of the Atlantic Ocean may be a direct consequence of a decline in the resilience of coastal ecosystems to disturbance. This decline was principally caused by decreasing diversity of predatory and/or herbivorous fish, and concomitant reductions in the diversity of many functional groups that inhabit the Atlantic Ocean (Myers \& Worm 2003). As a result, the structural and functional 
properties of the emergent dominant states differ significantly from the original states, resulting in less valuable ecosystems with fewer 'goods and services' being generated for society.

Acknowledgements. This manuscript benefited significantly from fruitful discussion and suggestions by H. A. Lessios and J. Lawrence. Linguistic suggestions by T. Dempster improved previous drafts of this paper.

\section{LITERATURE CITED}

Alves FMA, Chicharo LM, Serrao E, Abreu AD (2001) Algal cover and sea urchin spatial distribution at Madeira Island (NE Atlantic). Sci Mar 65:383-392

Alves FMA, Chicharo LM, Serrao E, Abreu AD (2003) Grazing by Diadema antillarum (Philippi) upon algal communities on rocky substrates. Sci Mar 67:307-311

Bellwood DR, Hughes TP, Folke C, Nystrom M (2004) Confronting the coral reef crisis. Nature 429:827-833

Briggs JC (1974) Marine zoogeography. McGraw-Hill, New York

Edmunds PJ, Carpenter RC (2001) Recovery of Diadema antillarum reduces macroalgal cover and increases abundance of juvenile corals on a Caribbean reef. Proc Natl Acad Sci USA 98:5067-5071

Estes JA, Tinker MT, Williamson TM, Doak DF (1998) Killer whale predation on sea-otters linking coastal with oceanic ecosystems. Science 282:473-476

Folke C, Carpenter SR, Walker B, Scheffer M, Elmqvist T, Gunderson L, Holling CS (2004) Regime shifts, resilience and biodiversity in ecosystem management. Annu Rev Ecol Evol Syst 35:557-581

Gardener TA, Cote IM, Gill JA, Grant A, Watkinson AR (2003) Long-term region-wide declines in Caribbean corals. Science 301:958-960

Graham MH (2004) Effects of local deforestation on the diversity and structure of southern California giant kelp forest food webs. Ecosystems 7:341-357

Hughes TP (1994) Catastrophes, phase shifts, and large scale degradation of a Caribbean coral reef. Science 265: $1547-1551$

Hughes TP, Bellwood DR, Folke C, Steneck RS, Wilson J (2005) New paradigms for supporting the resilience of marine ecosystems. Trends Ecol Evol 20:380-386

Knowlton N (2004) Multiple 'stable' states and the conservation of marine ecosystems. Prog Oceanogr 60:387-396

Lessios HA (1988a) Population dynamics of Diadema antillarum Philippi (Echinodermata: Echinoidea) following mass mortality in Panama. Mar Biol 99:515-526

Editorial responsibility: Howard I. Browman (Associate Editor-in-Chief), Storebø, Norway
Lessios HA (1988b) Mass mortality of Diadema antillarum in the Caribbean: what have we learned? Annu Rev Ecol Syst 19:371-393

Lessios HA, Robertson DR, Dubit DJ (1984) Spread of Diadema mass mortality through the Caribbean. Science 226:335-337

Lessios HA, Kessing BD, Pearse JS (2001) Population structure and speciation in tropical seas: global phylogeography of the sea urchin Diadema. Evolution 55:955-975

Lüning K (1990) Seaweeds: their environment, biogeography, and ecophysiology. Wiley Interscience, New York

Miller RJ, Adams AJ, Ogden NB, Ogden JC, Ebersole JP (2003) Diadema antillarum 17 years after mass mortality: is recovery beginning on St. Croix? Coral Reefs 22:181-187

Myers RA, Worm B (2003) Rapid worldwide depletion of predatory fish communities. Nature 423:280-283

Nedimyer K, Moe MA (2003) Techniques development for the reestablishment of the long-spined sea urchin, Diadema antillarum, on two small patch reefs in the upper Florida Keys. Joint Conf Sci Restoration Greater Everglades and Florida Bay Ecosystem, Palm Harbour, FL

Pandolfi M, Bradbury RH, Sala E, Hughes TP and 8 others (2003) Global trajectories of the long-term decline of coral reef ecosystems. Science 301:955-958

Pinnegar JK, Polunin NVC, Francour P, Badalamenti F and 7 others (2000) Trophic cascades in benthic marine ecosystems: lessons for fisheries and protected-area management. Environ Conserv 27:179-200

Sala E, Zabala M (1996) Fish predation and the structure of the sea urchin Paracentrotus lividus population in the NW Mediterranean. Mar Ecol Prog Ser 140:71-81

Sala E, Boudouresque CF, Harmelin-Vivien ML (1998) Fishing, trophic cascades, and the structure of algal assemblages: evaluation of an old but untested paradigm. Oikos 83:425-439

Scheffer M, Carpenter SR (2003) Catastrophic regime shifts in ecosystems: linking theory to observations. Trends Ecol Evol 18:648-656

Scheffer M, Carpenter S, Foley J, Folke C, Walker B (2001) Catastrophic shifts in ecosystems. Nature 413:591-596

Shears NT, Babcock RC (2003) Continuing trophic cascade effects after 25 years of no-take marine reserve protection. Mar Ecol Prog Ser 246:1-16

Tuya F, Boyra A, Sánchez-Jerez P, Haroun RJ, Barberá C (2004a) Relationships between rocky-reef fish assemblages, the sea urchin Diadema antillarum and macroalgae throughout the Canarian Archipelago. Mar Ecol Prog Ser 278:157-169

Tuya F, Boyra A, Sánchez-Jerez P, Haroun RJ, Barberá C (2004b) Can one species determine the structure of a rocky benthic community? The case of the long-spined sea urchin Diadema antillarum (Echinodermata: Echinoidea) in the eastern Atlantic. Hydrobiologia 519:211-214

Submitted: May 20, 2005; Accepted: August 11, 2005

Proofs received from author(s): October 19, 2005 